\title{
Umpires as Legal Realists
}

William Blake University of Texas, Austin

ABSTRACT During his confirmation hearings, then-judge John Roberts analogized the role of a judge to the role of a baseball umpire. Roberts argued that umpires do not make the rules; they simply apply them. Legal scholars have criticized Roberts from a legal realist perspective because the analogy misconstrues the nature of judging as formalistic. I believe Roberts also misconstrued the nature of umpiring as formalistic. Like judges, umpires must rely on their experience, rather than logic, because the rules of baseball are sometimes incomplete, indeterminate, and contradictory. On occasion, umpires even ignore the rulebook (justifiably). The judges-as-umpires analogy thus illustrates the differences between legal formalism and legal realism in a way that students can more easily understand.

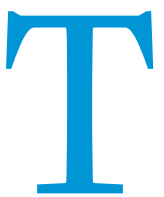

he nexus between law and baseball is strong (Aside 1974; Baum 1988; Osborne 2005; Waller and Cohen 1995). Thus, it is not surprising that then-judge John Roberts used a baseball analogy to describe his views of the role judges ought to play in the political sys-

purely formalistic approach to umpiring undermines the fundamental values of our national pastime, which is why umpires often interpret some rules generously or even ignore others for the good of the game. Let us not forget the strike zone, the definition of which is perhaps the worst artificial construct in the rulebook.

tem. During his confirmation hearings to become chief justice, Roberts (2005) stated: "Judges are like umpires. Umpires don't make the rules; they apply them. The role of an umpire and a judge is critical. They make sure everybody plays by the rules. But it is a limited role. Nobody ever went to a ballgame to see the umpire." Legal scholars (McKee 2006; Siegel 2007) and then-solicitor general Elena Kagan (Koppel 2010) have criticized this analogy because it mischaracterizes the nature of judging as formalistic. As a youth baseball umpire, I believe the message Roberts was communicating is flawed because it mischaracterizes the nature of umpiring as formalistic. A more accurate and detailed explanation of umpiring renders the analogy more useful by providing a culturally accessible illustration of the differences between legal formalism and legal realism.

Umpires encounter many of the same problems legal realists think that judges face: the rules of baseball are sometimes incomplete, contradictory, and made of artificial constructs that are difficult to apply in the real world. Further, a

William Blake is a doctoral candidate in the government department at the University of Texas, Austin and a member of the Central Texas Umpire Association. He can be reached at william.blake@utexas.edu.
Figure 1

Retired US Supreme Court Justice Sandra Day O'Connor reminds the umpires to be fair, after delivering the first ball to the crew, before a baseball game between the Colorado Rockies and the Chicago Cubs, May 18, 2010, at Wrigley Field, Chicago.

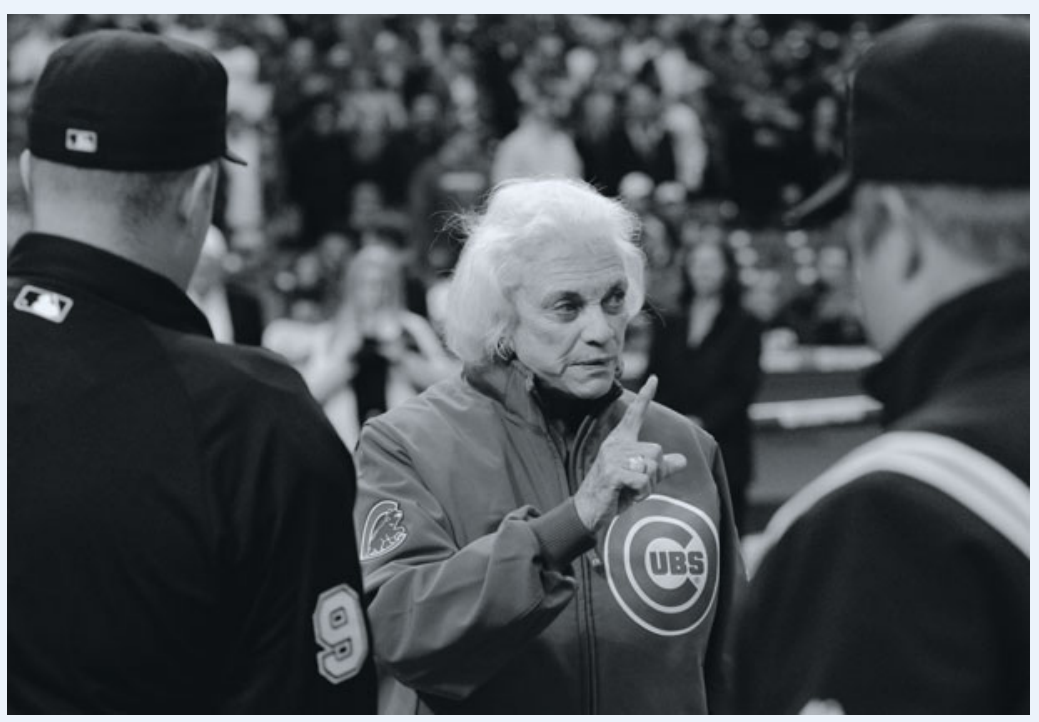

Source: AP Photo/Charles Rex Arbogast 
Former Mets pitcher Ron Darling (as cited in Weber 2009a, 167) once quipped: "I can't really describe what a strike is, but I know it when I see it." This statement echoes justice Potter Stewart (Jacobellis v. Ohio 1964, 196) when he said that he could not define hard-core pornography, "[b] ut I know it when I see it." Whether the object is a twelve-to-six curveball or a racy movie, umpires and judges often cannot formalistically apply rules.

\section{UNDERSTANDING THE ANALOGY: GROUND RULES}

What exactly did Chief Justice Roberts mean by comparing the proper role of a judge to the proper role of an umpire? ${ }^{1}$ There are several components to this analogy. First, Roberts compared the game of baseball to a legal dispute. Under his theory, judges should be impartial and leave aside their preferences, such as a like or dislike of one party. Second, judges must "call 'em as they see 'em." Roberts agreed with senator John Cornyn's (as cited in "Second Day of Hearings on the Nomination of Judge Roberts" 2005) suggestion that, just as umpires strive to classify pitches as balls and strikes objectively, "there are right answers" to legal questions. Third, a judge is constrained by the rules of the game. One implication of this tenet is that judges must follow precedent, even if they disagree with it. ${ }^{2}$ Fourth, all of these ideas tie together in the notion that a judge, like an umpire, should not be conceived of as a player in the game, but instead merely a neutral observer.

On the surface, this comparison is somewhat useful. If judges have a relationship with one party in a case that puts their objectivity in question, ethically they must recuse themselves. Further, judges strive to answer questions of fact objectively and answer questions of law without regard to who benefits from those determinations. The comparison of being constrained by the rulebook also has some limited value. An umpire cannot give one batter assumes every legal controversy has a rule governing its resolution, much like Chief Justice Roberts assumed the baseball rulebook contains a method of handling every controversy on the diamond.

Judge Theodore McKee $(2006,1710)$ critiqued this model of judging stemming from the umpire analogy, calling it a "mechanical manner that is removed from society and its many forces." Although Judge McKee believes that detachment in judicial decisionmaking is a noble goal in most situations, he acknowledges that some situations in which a judge's experiences and beliefs improve jurisprudence, rather than detract from it. For example, judges must consider whether police conduct "shocks the conscience" (Rochin v. California 1952), which is difficult for judges to do if they check their consciences at the courthouse door. Judge McKee also criticized the analogy in that umpires know which rules to apply, even if the play is a close call. Judges, in contrast, have difficulty determining which legal principle applies in a case.

Professor Neil Siegel $(2007,703)$ echoed this critique, arguing that the judges-as-umpires analogy falsely assumes that the law is "autonomous of contested social values, fixed in advance, politically neutral, and susceptible of relatively uncontroversial application." If Chief Justice Roberts' analogy were true, the public would not care who served on the Supreme Court because the law's meaning would be universally clear. Siegel concluded that judges are more than umpires-they are also players in the game because the Constitution is more than just a series of legal rules. It is also a list of American values, some of which are imprecisely defined.

Both of these critiques embrace, to some degree, a legal realist perspective. As Justice Cardozo (1922) observed, judges often need to interpret indeterminate legal concepts, such as reasonable care, unreasonable restraint of trade, or due process. Because these con-

\section{An umpire cannot give one batter four strikes before calling him out (Dworkin 1978, 24), nor can a judge ignore the Constitution and allow a state to pass a statute denying the vote to women.}

four strikes before calling him out (Dworkin 1978, 24), nor can a judge ignore the Constitution and allow a state to pass a statute denying the vote to women. Judges are also constrained in that their authority exists only when a controversy needs resolution. Umpires cannot call an out at second base if there is no play at second, and federal judges cannot render advisory opinions (Allen 2009, 534). Likewise, the Constitution is the ultimate source of law in this country, just as the rulebook is in a baseball game. However, the above comparisons give little meaningful insight into the role judges ought to play in American democracy.

In the previous analogy, the heart of the message Chief Justice Roberts conveys is that judges are not players in the political process and must merely apply the law rather than make law through interpretation. The inference is that judges ought to engage in legal formalism, which requires judges "to apply in every case, according to the meanings, the legal norms he or she can derive textually, conceptually, or through precedent." Furthermore, legal formalism forbids judges from considering "the norm's purposes, the general policies underlying the legal order, or the extrajuristic preferences of the interpreter" (Kennedy 2001, 8634-35). This view cepts are abstract, precedents often conflict, and judges can often use multiple legal principles to resolve the same question. Justice Cardozo suggested that judges ought to view their role with an eye to promoting societal welfare. Justice Oliver Wendell Holmes $(1909,5)$, another prominent realist, outlined another solution to this quandary of subjectivity:

The life of the law has not been logic: it has been experience. The felt necessities of the time, the prevalent moral and political theories ... even the prejudices which the judges share with their fellow-men, have a great deal more to do than the syllogism in determining the rules by which men should be governed.

Legal theorists have demolished small forests arguing over the accuracy of the legal realist critique (see Tamanaha 2009). I intend to destroy an additional tree or two by evaluating legal realism in the context of umpiring a baseball game.

\section{COMPARING LEGAL RULES AND THE RULES OF BASEBALL}

The formalist presupposition that the legal framework provides a comprehensive set of rules to adjudicate conflicts is not true in 
the world of umpiring. For example, the Official Rules of Major League Baseball (Playing Rules Committee 2010) does not define the boundaries of a check swing. By convention, baseball fans, players, and umpires alike accept that if a batter makes a partial swing at a pitch, but the bat does not break the plane of home plate, the batter has not made a swinging strike. Despite the fact that check swings occur frequently, its definition is completely extratextual. This practice could be thought of as umpires developing a baseball common law, an organic process driven by experience over time much like the origin of the infield fly rule (Aside 1974), which is now part of the rulebook. Likewise, Holmes (1909) put faith in the common law because of its potential to evolve based on changing circumstances.

The baseball rulebook also explicitly acknowledges its incompleteness in two separate passages. Rule 3.13 (Playing Rules Committee 2010) provides that both managers must agree to any stadium-specific ground rules, norms such as defining a home run. In some stadiums, a ball is considered a home run if it hits one of the support beams at the top of a domed stadium (Tampa Bay Rays 2011). If the managers cannot agree to these ground rules, the umpire has the authority to impose them, as he sees fit. Furthermore, Rule 9.01(c) states: "Each umpire has authority to rule on any point not specifically covered in these rules." One prominent example of invoking Rule 9.01(c) occurred in the 1989 World Series between the Oakland A's and San Francisco Giants. The Series was suspended for 10 days following the massive Bay Area earthquake. When play resumed, the umpires told both man- one that does not hold true in Major League Baseball practice. Rule 1.01 (2010) states: "Baseball is a game between two teams of nine players each." How then does one classify a designated hitter in the American League? Rule 6.10(b) (1) states that an American League manager's lineup card can list 10 players, with one being the designated hitter. Yet when it comes to defining the essence of baseball, the designated hitter is not given full baseball citizenship.

On a more serious note, there are three different standards in the rules concerning runner interference. In one section of the rulebook, a batter becomes a runner when "a fair ball, after having passed a fielder other than the pitcher, or after having touched by a fielder, including the pitcher, shall touch an umpire or runner on fair territory" (Rule 6.09(c)) (emphasis added). Later in the rulebook, a runner is declared out and a dead ball occurs if a runner touches a batted ball before it "has touched or passed an infielder" (Rule 7.08(f)) (emphasis added). ${ }^{3}$ Under this latter version of the rule, it seems that any batted ball that has traveled past the pitcher-who is an infielder (Rule 2.oo, Infielder)-and then hits a runner should not result in the umpire calling the runner out. Umpires instead tend to use the former definition laid out in Rule 6.09(c) and would call the runner out in this situation, assuming the rest of the infielders were playing at normal depth behind the runner.

Baseball rules, like statutes and constitutions, are often littered with indeterminate language. The rules task umpires with determining whether an infielder intentionally drops a fly ball to turn a double but without guidance on determining intentional-

\section{Judges often need to interpret indeterminate legal concepts, such as reasonable care, unreasonable restraint of trade, or due process. Because these concepts are abstract, precedents often conflict, and judges can often use multiple legal principles to resolve the same question.}

agers before the game that they would impose the following rule: if a tremor occurred while a ball was in play, it would be treated as a live ball that just happened to take a (potentially huge) bad hop (Bush 1989).

Umpires rarely need to invoke this provision, but this rule is still significant in that the framers of the game of baseball gave umpires the power to round out the rulebook when needed. These examples undercut Chief Justice Roberts' analogy when it assumed that umpires do not "make the rules." This does not mean that umpires are or should be partisan. When umpires have to fill in gaps in the rules, they do so with an eye on the good of the game, not as a way of supporting one team over the other.

The baseball rulebook delegates a great deal of interpretive authority to umpires. Any judgment call made by an umpireballs and strikes, safe or out at first base-may not be grounds to protest a game, even if the umpire clearly errs in making these calls (Playing Rules Committee 2010, Rule 4.19). In fact, the rulebook forbids managers and players from arguing with an umpire over judgment calls (Rule 9.01(a)), although in practice this regularly occurs. The phrase "in the umpire's judgment" is prevalent throughout the rulebook.

The rules of baseball, much like the legal system, also are in conflict with themselves. In fact, the very first rule of baseball is ity (Rule 6.05(1)). The baseball rulebook defines a quick pitch as an illegal pitch designed "with obvious intent to catch a batter off balance," but there is no definition of obvious intent (Rule 2.00, Quick Return). Similarly, a team is supposed to forfeit a game to their opponents if, in the umpire's judgment, it engages in "tactics palpably designed to delay or shorten the game" (Rule 4.15(b)). Forfeiting a game is the umpire's most powerful weapon to resolve a breach of the rules, and one might assume that rules would contain specific language to guide the umpire in his decision to invoke forfeiture. Alas, the rules do not define what "palpably designed" means. Umpires are instructed to stop a game when encountering "unsuitable weather conditions" (Rule 3.10(c)), but the rules do not include a definition of unsuitability. Rather than relying on specific textual guidance, umpires resolve the indeterminacy of baseball rules in a Holmesian fashion, based on their experience. In his book on professional baseball umpiring, journalist Bruce Weber (2009a, 181) noted the delicate nature of deciding when to halt a game due to inclement weather: "It takes experience; it takes a sense of being able to draw an imaginary line, in this case between tolerable and intolerable playing conditions. And it involves balancing the concerns of different constituencies. You don't really learn how to do it until you've done it a number of times." 
Experience also helps umpires translate baseball rules that are artificial constructs into concepts with real-world applicability. For example, the infield fly rule should only be invoked if a fly ball is hit that can be caught by an infielder with ordinary effort. Unlike other indeterminate phrases, the rulebook does define ordinary effort, but not very clearly. Ordinary effort is "the effort that a fielder of average skill at a position in that league or classification of leagues should exhibit on a play, with due consideration given to the condition of the field and weather conditions" (Playing Rules Committee 2010, Rule 2.oo, Ordinary Effort). This definition requires umpires to analyze data concerning fielding skills, a baseball version of sociological jurisprudence (Cardozo 1922).

Perhaps the most artificial construct in the baseball rulebook is the strike zone, which is defined (Playing Rules Committee 2010, Rule 2.0o Strike Zone) as:

[T] hat area over home plate the upper limit of which is a horizontal line at the midpoint between the top of the shoulders and the top of the uniform pants, and the lower level is a line at the hollow beneath the kneecap. The Strike Zone shall be determined from the batter's stance as the batter is prepared to swing at a pitched ball.

This definition is plagued with terms that are difficult to translate into adjudication, which is probably why the Major League Baseball rulebook also includes a pictorial diagram demonstrating where the midpoint of the torso and the hollow beneath the knee are actually located on a batter. In addition, the rulebook does not attempt to define a legal batting stance. In theory, a major leaguer seeking a walk could take his stance in a squatting position to shrink the strike zone to a bare minimum, although umpires do have discretion to eject players for unsportsmanlike conduct (Rule 9.01(d)).

Even experienced major league umpires have difficulty putting the definition of a strike into action. Durwood Merrill (as cited in Weber 2009a, 171), a 20-year veteran, said in an interview that he wore kneepads during one postseason that included a diagram sketched on them, intended as a joke. Two lines crossed the kneepads, one just above the knee and one just below. Above the top line he wrote the word "strike," and he wrote "ball" below the bottom line. In the area in between, the diagram read "not sure." Thus, the strike zone requires good judgment from an umpire, not just a thorough understanding of the rules. Chief Justice Roberts' portrayal of umpires, assumes anyone who knows the rulebook and has good eyesight can easily enforce the strike zone (Graber 1999).

In his interviews with major league umpires, Weber (2009a, 72) reports that several umpires describe calling balls and strikes as "a kind of political enterprise, an activity requiring will and conscience and a point of view." Gary Cederstrom (as cited in Weber 2009a, 72), who umpired the 2007 American League Championship Series, told Weber: "It's like the Constitution... The strike zone is a living, breathing document." The connection between the theory of a living Constitution and legal realism is a strong one. Justice Holmes (Missouri v. Holland 1920, 433) once stated: "It was enough for [the framers of the Constitution] to realize or to hope that they had created an organism." Even political commentator George Will (as cited in Weber 2009a, 167), who likely does not fancy himself a believer in a living Constitution, quipped: "If the Constitution is what the Supreme Court says it is, then the strike zone is what umpires say it is."
Despite the malleability of the strike zone, umpires routinely apply it in a manner inconsistent with the rulebook's definitionthey almost never call a strike above a player's belt (Sullivan 2001). Much like the common law that Holmes adored so much, the strike zone has evolved over time through the changing interpretations of umpires. Umpires began shrinking the upper end of the strike zone around the 1960 s perhaps to restore greater competitive balance between batter and pitcher (Linder 1987). Not only did future umpires continue the trend of older umpires, this evolving norm gained acceptance by players, managers, and the commissioner as well. ${ }^{4}$

Even when the rulebook defines a concept that is easily comprehensible-such as tagging a runner-umpires still rely on extralegal norms, derived from experience, to help resolve very close plays. If a runner attempts to steal a base or stretch a double into a triple and the throw from the defender reaches the base before the runner does, more often than not, umpires will call the runner out, even if it is possible that the runner actually avoided the tag. These plays are often very close and could go either way; umpires use this rule of calling a runner out as a pragmatic solution to a difficult situation (Weber 2009b). This presents a similar dilemma that Justice Cardozo (1922) finds with precedent-often judges can find support for either litigant's case and the judge is tasked with finding a workable solution.

The most fundamental rule of umpiring is to keep the game operating smoothly and safely, and umpires can seriously undermine this goal by applying the rulebook formalistically in all circumstances. Umpires tend to adopt a Cardozo-like approach to their decisionmaking: their calls should promote societal welfare, or, more specifically, the good of the game of baseball. Consider what a formalistic application of the rules of baseball would require of an umpire when infielders attempt to turn a double play. The rules of baseball state a fielder can only record a force out if he has secure possession of the ball and touches a base before the runner arrives there. In real life, often when the shortstop flips the ball to the second baseman, the second baseman will be near second base, without actually touching it, before throwing on to first base to complete the double play. In this situation, called the "neighborhood play," the umpire will still call the runner out at second base.

If the rulebook provides a clear definition of a force out, why does the umpire ignore the rulebook? Umpires do this to protect the safety of the second baseman. If the second baseman were required to touch second base before throwing on to first base in this situation, he risks a collision with the runner sliding into second. In fact, runners are taught to attempt to break up a double play by colliding with middle infielders, thereby disrupting their throw to first base. Thus, the second baseman will touch an area near second base that will allow them to be far enough away from the sliding runner to complete the throw to first safely. Major League umpire Tom Hallion (as cited in Weber 2009a, 115) said in an interview: "You would give him the call even if he's not right on the bag ... [b] ecause if I call the guy safe, here's what [the defensive team's coaches] say: 'Do you want this guy [expletive] killed?"

In fact, the social practice of baseball has incorporated the "neighborhood play" to the point that when an umpire refuses to apply it, a controversy ensues. Consider the 2009 American League Championship Series between the Los Angeles Angels of Anaheim and the New York Yankees. The Yankees had a runner on first base in the 1oth inning of Game Two when Macier 
Izturis, the Angels second baseman, fielded a ball up the middle, flipped it to shortstop Erik Aybar, whose foot was several inches from second base when he threw the ball on to first base. Umpire Jerry Layne refused to call an out at second, which caused Angels manager Mike Scoscia to bolt out from the dugout to argue. As journalist Kevin Kaduk (2009) noted afterwards, "Strange as it sounds to outsiders, [the neighborhood play] is considered a part of baseball."

\section{THE IMPORT OF LAW AND SPORTS OFFICIATING ANALOGIES}

Certainly I am not the first person to deconstruct the judges-asumpires analogy with an eye on how umpires actually operate. Professor Mark Graber $(1999,313)$ rightly calls himself the "true founder of the 'law and sports officiating movement." Graber argued that sports officials often stretch, or ignore otherwise, clear rules, such as when umpires in a recreational softball league adopt a wide strike zone to encourage players to swing more frequently. Similarly, he pointed out that officials in other sports often must make interpretive judgments of indeterminate rules, such as a "flagrant foul" in basketball. Professor Michael Allen (2009) likewise attempted to build a more realistic view of umpiring, noting the indeterminacy of some baseball rules that require umpires to make interpretations based on their judgment. Allen ultimately concluded that Chief Justice Roberts' judges-as-umpires analogy is, at least partially useful, in describing the role of courts in American society. Neither Graber nor Allen attempted to place umpires or other sports officials in a jurisprudential school of thought. I contend, however, that umpiring can be often be thought of as a realist enterprise.

Aaron Zelinsky (2011) reframed the baseball analogy such that Supreme Court justices become the equivalent of the Commissioner of Baseball. Both entities provide guidance to subordinates, engage in deliberation, fill in gaps in the law, and yield discretion. This approach has several problems. First, the ultimate source of baseball authority is the Commissioner of Baseball, but the ultimate source constitutional legitimacy is not the Supreme Court, but rather "We the People" (McCulloch v. Maryland 1819). The Commissioner of Baseball, through his delegation to the Playing Rules Committee, writes the rulebook. In the United States, Congress writes the laws, while judges do not directly write the law. Second, as I have argued in this article, umpires, not the commissioner, must regularly fill in gaps in the rulebook to keep the game running smoothly and fairly. Finally, umpires, more so than the commissioner, wield a great deal of discretion granted to them by the rulebook.

I believe the judges-as-umpires analogy holds some utility because it helps explain the differences between legal formalism and legal realism by examining the contrast between Chief Justice Roberts' conception of the analogy and the one embraced herein. Chief Justice Roberts mischaracterizes the nature of umpiring by asserting that umpires are little more than automatons tasked with implementing a thorough set of rules and not playing a role in the game. In reality, the rules of baseball, like statutes and constitutions, are sometimes incomplete, conflicting, and full of indeterminate phrases and artificial constructs. This conundrum requires both umpires and judges to make subjective, interpretive judgments based on their experience and the welfare of their respective communities. Formalistic approaches to law and umpiring often can be socially destructive because the decision maker is not allowed to consider the underlying utility of the rule they are asked to enforce.

This tension between legal formalism and legal realism does not exist in every situation either in the courtroom or on the field. Quite often, legal statutes are clear, comprehensive, and useful, and judges do not need to engage in subjective judgments to apply them. Likewise, many strikes that umpires call are so obvious that no fan or player can dispute the call. Nevertheless, when there is a conflict between formalism and realism, the judges-as-umpires analogy, when properly constructed, can provide a lens through which to understand the differences between these two fundamental theories of jurisprudence. This analogy, when considered from the two different perspectives discussed here, might be an easier way to introduce the concepts of legal formalism and legal realism to undergraduate students by harnessing our nation's pastime as an explanatory vehicle. No analogy can fully explain how one institution works because analogies, by definition, invite comparisons to institutions that are different. However, analogies are a useful way of breaking down a complex topic (like judging) in terms of a more easily understood topic (such as umpiring) (Levinson 1985).

Chief Justice Roberts might have assumed that no one ever went to a ballgame to watch the umpire, but when the game is on the line, the umpire is the most watched person in the stadiumJustice Kennedy wearing a mask instead of a robe. Hating umpires for ruling against the home team in a close play is an old baseball tradition (Weber 2009a), and Supreme Court justices often receive just as much invective when they issue unpopular decisions. This sort of reaction, either on the field or in the courtroom, should come as no surprise given the subjective roles played by American umpires and judges.

\section{ACKNOWLEDGEMENT}

Many thanks to my mother, Linda Blake, for inspiring my love of the game.

\section{NOTES}

1. Other jurists have made an analogy to umpiring (Abrams 2010).

2. This posed a problem for Chief Justice Roberts at his confirmation hearings when several senators questioned whether under this logic, the Supreme Court could have rendered its decision in Brown v. Board of Education (1954) if it were tightly constrained by its prior segregationist precedent. Chief Justice Roberts (as cited in "Second Day of Hearings on the Nomination of Judge Roberts" 2005) stated he believed there was precedent supporting the Court's decision in Brown.

3. Rule 7.04(b) uses a similar definition of interference. Further complicating matters is a third definition employed in Rules 5.09(f), 6.05(g), 6.08(d), and $7.09(\mathrm{k})$, which calls for a dead ball when a fair ball touches a runner "before it touches an infielder including the pitcher" (emphasis added).

4. This example of adjudicator-initiated social change meets the criteria set forth by Rosenberg (1993).

\section{REFERENCES}

Abrams, Douglas E. 2010. "Sports in the Courts: The Role of Sports References in Judicial Opinions.” Villanova Sports and Entertainment Law Journal 17: 1-58.

Allen, Michael P. 2009. "Alternative Visions of the Judicial Role: A Limited Defense of (at Least Some of) the Umpire Analogy." Seattle University Law Review 32 (Spring): 525-47.

Aside. 1974. "Common Law Origins of the Infield Fly Rule." University of Pennsylvania Law Review 123: 1474-81.

Baum, Lawrence. 1988. "Measuring Policy Change in the U.S. Supreme Court." The American Political Science Review 82 (3): 905-12.

Brown v. Board of Education. 1954. 347 U.S. 483. 
Bush, David. 1989. "Series Video Outdoes The Games." San Francisco Chronicle, D2.

Cardozo, Benjamin N. 1922. The Nature of the Judicial Process. New Haven, CT: Yale University Press.

Dworkin, Ronald. 1978. Taking Rights Seriously. Cambridge, MA: Harvard University Press.

Graber, Mark A. 1999. "Law and Sports Officiating: A Misunderstood and Justly Neglected Relationship." Constitutional Commentary 16: 293-314.

Holmes, Oliver Wendell. 1909. The Common Law. New York: Little, Brown.

Jacobellis v. Ohio. 1964. 378 U.S. 184.

Kaduk, Kevin. 2009. "Erick Aybar's Footwork (or Lack Thereof) Creates a Giant Gray Area." Yahoo Sports. http://sports.yahoo.com/mlb/blog/big_league_stew/ post/Erick-Aybar-s-footwork-or-lack-thereof-creates?urn=mlb,196580 (Accessed May 7, 2010).

Kennedy, Duncan. 2001. "Legal Formalism." In International Encyclopedia of the Social and Behavioral Sciences, ed. Neil J. Smelser and Paul B. Baltes. New York: Elsevier.

Koppel, Nathan. 2010. "Are Judges Umpires? Eh, Not Exactly, Says Kagan.” Wall Street Journal. http://blogs.wsj.com/law/2010/o6/30/are-judges-umpires-eh-notexactly-says-kagan/ (Accessed April 20, 2011).

Levinson, Sanford. 1985. "On Interpretation: The Adultery Clause of the Ten Commandments.” Southern California Law Review 58: 719-26.

Linder, Douglas O. 1987. "Strict Constructionism and the Strike Zone." UMKC Law Review 56: 117-20.

McCulloch v. Maryland. 1819. 17 U.S. 316.

McKee, Theodore A. 2006. "Judges as Umpires." Hofstra Law Review 35: 1709-24.

Missouri v. Holland. 1920. 252 U.S. 416.

Osborne, Amy Beckham. 2005. "Baseball and the Law: A Selected Annotated Bibliography, 1990-2004." Law Library Journal 97: 335-70.
Playing Rules Committee. 2010. "Official Baseball Rules." http://mlb.mlb.com/mlb/ official_info/official_rules/foreword.jsp (Accessed July 11, 2010).

Roberts, John. 2005. "'I Come Before the Committee With No Agenda. I Have No Platform."” The New York Times, 28.

Rochin v. California. 1952. 342 U.S. 165.

Rosenberg, Gerald N. 1993. The Hollow Hope: Can Courts Bring about Social Change? Chicago: University Of Chicago Press.

"Second Day of Hearings on the Nomination of Judge Roberts." 2005. The New York Times. http://www.nytimes.com/2005/o9/13/politics/politicsspecial1/13textroberts.html?pagewanted $=100$ (Accessed July 11, 2010).

Siegel, Neil S. 2007. "Umpires at Bat: On Integration and Legitimation." Constitutional Commentary 24: 701.

Sullivan, Tim. 2001. "High Time for 'New' Strike Zone." Cincinnati Enquirer. http:// reds.enquirer.com/2001/02/25/red_high_time_for_new.html (Accessed April 23, 2011).

Tamanaha, Brian Z. 2009. Beyond the Formalist-Realist Divide: The Role of Politics in Judging. Princeton, NJ: Princeton University Press.

Tampa Bay Rays. 2011. "Tropicana Field Ground Rules.” Tropicana Field Information. http://tampabay.rays.mlb.com/tb/ballpark/information/ index.jsp?content $=$ ground_rules (Accessed April 25, 2011).

Waller, Spencer W., and Neil B. Cohen. 1995. Baseball and the American Legal Mind. New York: Routledge.

Weber, Bruce. 2009a. As They See 'Em: A Fan's Travels in the Land of Umpires. Scribner.

- 2009b. "Umpires v. Judges." The New York Times. http://www.nytimes.com/ 2009/07/12/weekinreview/12weber.html?hp (Accessed July 27, 2009).

Zelinsky, Aaron. 2011. "The Justice as Commissioner: Benching the Judge-Umpire Analogy." Yale Law Journal Online 121: 126-75. 